Artikel Penelitian

\title{
Evaluasi Frame Sepeda saat Tabrakan Dengan Metode Ekplisit Elemen Hingga
}

\author{
Ardi Wiranata ${ }^{a}$, Abdul Arief ${ }^{b}$, Heru Santoso B $R^{a}$ \\ ${ }^{a}$ Departemen Teknik Mesin dan Industri, Fakultas Teknik, Universitas Gadjah Mada, Jalan Grafika No. 2, Yogyakarta 55281, \\ Indonesia \\ b PT. Indonesia Epson Industry, EJIP Industrial Park Plot 4E Cikarang Selatan, Bekasi 17550, Indonesia
}

\section{INFORMASI ARTIKEL}

\section{Sejarah Artikel:}

Diterima Redaksi: 08 Februari 2019

Revisi Akhir: 22 Maret 2019

Diterbitkan Online: 29 April 2019

KATA KunCI

Energi tabrakan

Frontal impact

Komposit

FEA

KORESPONDENSI

E-mail: ardi.wiranata@ugm.ac.id

\begin{abstract}
A B S T R A C T
In this paper, numerical method of crash impact by using explicit dynamic model was used to evaluate the bike frame design. Frontal impact simulation model was carried out to understand the characteristics of energy absorption, stress distribution and deformation of the bike frame. Carbon fiber T300 composite with elasticity modulus $129,79 \mathrm{GPa}$ and overall frame weight is 1,8 $\mathrm{kg}$ was used in this simulation as material properties. Hashin damage criteria was used in this numerical analysis since this criteria was widely used to assess composite material damage simulation. In this study Head Tube angle (HTA) and Top Tube Angle (TTA) was modified. The modified HTA was varied from $69^{\circ}$ to $76^{\circ}$ and TTA was $70^{\circ}$ to $86^{\circ}$. This modification was based on the original frame design which the HTA and TTA are $71.5^{\circ}$ and $74^{\circ}$ respectively. This modification was aimed to find the effect of HTA and TTA modification to energy absorption and stress distribution in the bike frame design. Simulation result shows that TTA and HTA modification affect the energy absorption of the bike frame. The smaller the energy absorption of the bike frame shows that the frame has poor quality of stress distribution.
\end{abstract}

\section{PENDAHULUAN}

Salah satu kriteria keselamatan penumpang pada kendaraan adalah jumlah energi yang dapat diserap pada rangka utama kendaraan. Keamanan penumpang kendaraan tergantung dengan kemampuan rangka kendaraan dalam menyerap energi saat tabrakan. Hal ini menjadi salah satu faktor dalam pemilihan material. Baru - baru ini berkembang material yang memiliki kemampuan penyerapan energi yang baik yaitu material komposit [1].

Komposit serat karbon banyak dipakai oleh beberapa kendaraan sebagai pengganti material struktur rangka. Komposit serat karbon biasanya digunakan pada beberapa bagian pada kendaraan diantaranya: bagian bodi mobil, beberapa bagian sayap pesawat terbang, baling-baling pesawat terbang dan juga pada frame sepeda. Frame sepeda dengan bahan komposit serat karbon telah banyak dikembangkan untuk memperoleh rangka yang kuat dan ringan.

Penggunaan komposit serat karbon pada frame sepeda balap akan memberikan implikasi pada turunnya berat keseluruhan dari sepeda balap tersebut tanpa mengurangi kekuatan dari frame tersebut. Namun demikian, pengujian untuk mengetahui tingkat keamanan dari penggunaan rangka komposit serat karbon perlu dilakukan dengan teliti. Salah satu pengujian yang dapat 
dilakukan untuk mengetahui tingkat reliability dari frame sepeda balap adalah dengan uji impact pada frame sepeda. Salah satu metode uji impact untuk frame sepeda ini adalah sesuai dengan standar EN1481 yaitu dengan menggunakan metode drop mass impact. Uji drop mass impact dilakukan untuk menguji kekuatan frame sepeda dalam menahan besaran beban yang dijatuhkan dan mengenai bagian depan sepeda. Selain itu, untuk menguji kekuatan dari frame sepeda dapat dilakukan juga dengan uji tabrakan pada frame sepeda. Uji tabrakan ini diakukan untuk menghitung besarnya energi yang dapat diserap oleh rangka. Meskipun demikian, pengujian rangka akan memakan biaya yang mahal jika harus menggunakan metode destructive test. Sehingga untuk menanggulangi besarnya biaya yang diperlukan untuk uji tabrakan, metode analisis eksplisit elemen hingga dapat menjadi trobosan baru dalam perhitungan besarnya penyerapan energi oleh rangka sepeda saat terjadi tabrakan.

Metode ekplisit dinamik elemen hingga adalah salah satu metode untuk menganalisis atau memahami fenomena respon struktur material terhadap pembebanan yang berubah-ubah terhadap waktu. Beberapa contoh penggunaan eksplisit dinamik adalah pada simulasi tabrakan, ledakan, dan drop impact. Pada fenomena tabrakan, metode ekplisit dinamik elemen hingga dapat juga digunakan untuk menganalisis besarnya penyerapan energi pada struktur rangka sepeda.

Pada penelitian ini dilakukan perhitungan besarnya penyerapan energi, distribusi tegangan dan deformasi pada rangka sepeda serat karbon dengan menggunakan metode eksplisit elemen hingga. Simulasi dilakukan dengan menggunakan software ABAQUS untuk menguji frontal impact pada rangka sepeda. Hasil yang didapat dari hasil simulasi akan digunakan sebagai acuan untuk melakukan modifikasi HTA dan TTA pada rangka sepeda.

\section{METODOLOGI}

Pada penelitian ini, simulasi dilakukan dengan menggunakan metode eksplisit dinamik untuk menganalisa energi yang diserap frame sepeda ketika ditabrakan ke dinding. Desain sepeda yang digunakan adalah sepeda balap serat karbon hasil riset Junaidi, dkk (2016) [2]. Penelitian serupa dengan metode eksplisit dinamik juga pernah dilakukan oleh Lin (2017)[3]. Pada penelitian tersebut, optimalisasi dilakukan dengan menggunakan dua parameter faktor kontrol diantaranya : Head Tube Angle (HTA) dan Top Tube Angle (TTA). Ketebalan pipa pembentuk frame dianggap sama untuk semua desain yaitu $2 \mathrm{~mm}$. Batasan modifikasi HTA dan TTA pada penelitian ini adalah $69-76^{\circ}$ dan $70-86^{\circ}$. Gambar detail posisi HTA dan TTA dapat dilihat pada Gambar 1. Ukuran sepeda sebelum dilakukan modifikasi HTA dan TTA dapat dilihat pada Tabel 1. Sedangkan fariasi modifikasi frame sepeda dapat dilihat pada Tabel 2.

Tabel 1. Ukuran Original Frame Sepeda Balap

\begin{tabular}{ccc}
\hline $\begin{array}{c}\text { Ukuran Frame } \\
\text { Sepeda }\end{array}$ & $\begin{array}{c}\text { HTA } \\
\text { Head Tube } \\
\text { Angle }\left(^{\circ}\right)\end{array}$ & $\begin{array}{c}\text { TTA } \\
\text { Top Tube } \\
\text { Angle }\left(^{\circ}\right)\end{array}$ \\
\hline $\begin{array}{l}\text { Original Frame } \\
\text { Sepeda Balap }\end{array}$ & 71.5 & 74 \\
\hline (Sumber: Junaidi, 2016) & &
\end{tabular}

(Sumber: Junaidi, 2016)

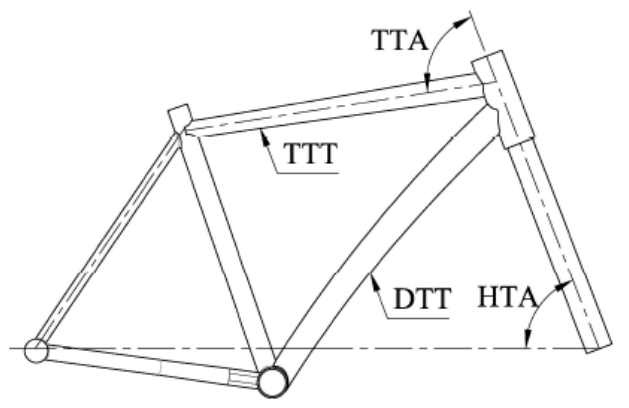

Gambar 1. Posisi Head Tube Angle (HTA) dan Top Tube Angle (TTA) [3] 
Tabel 2. Modifikasi sudut HTA dan TTA

\begin{tabular}{cccc}
\hline No & $\begin{array}{c}\text { HTA } \\
(\text { Head Tube } \\
\left.\text { Angle }^{\circ}\right)\end{array}$ & $\begin{array}{c}\text { TTA } \\
(\text { Top Tube } \\
\text { Angle }\end{array}$ & Kode \\
\hline 1 & 71.5 & 70 & T1 \\
2 & 71.5 & 73.2 & T2 \\
3 & 71.5 & 76.4 & T3 \\
4 & 71.5 & 79.6 & T4 \\
5 & 71.5 & 82.8 & T5 \\
6 & 71.5 & 86 & T6 \\
7 & 69 & 74 & H1 \\
8 & 70.4 & 74 & H2 \\
9 & 71.8 & 74 & H3 \\
10 & 73.2 & 74 & H4 \\
11 & 74.6 & 74 & H5 \\
12 & 76 & 74 & H6 \\
\hline
\end{tabular}

\subsection{Simulasi Frontal Impact pada Frame Sepeda Balap}

Frontal Impact dilakukan dengan cara menabrakan frame sepeda tanpa fork ke sebuah model papan yang dianggap solid dan tidak mengalami deformasi. Hal ini dilakukan untuk melihat besarnya energi yang dapat diserap pada frame sepeda ketika mengalami tabrakan. Pada proses simuasi terdapat beberapa tahap yang harus dilalui diantaranya: Meshing part, assembly part, step, interaction part, load, dan submit simulation. Interaction part dan meshing part merupakan tahapan yang paling menentukan tingkat akurasi dari simulasi.

Dalam simulasi ini material yang dipakai adalah komposit serat karbon tipe T300. komposit serat karbon tipe ini memiliki massa jenis komposit $1371 \mathrm{~kg} / \mathrm{m}^{3}$, Modulus Elastisitas 129.79 GPa dan poisson ratio ratio 0,3 . Kriteria kegagalan yang digunakan dalam proses simulasi ini adalah Hashin damage. Penjabaran kriteria Hashin ini telah dijabarkan secara lengkap pada beberapa penelitian sebelumnya [4,5]. Kriteria kerusakan Hashin merupakan hasil karya Hashin dan Rotem. Kriteria kegagalan ini berbeda dengan kriteria polinomial seperti kriteria Tsai-Hill dan Tsai-Wu, dimana pada persamaan tersebut diusulkan persamaan tunggal untuk memprediksi inisiasi retakan.
Kriteria kegagalan Hashin ini memperhitungkan empat mode kegagalan yaitu: kerusakan serat dalam ketegangan, fiber buckling, matrix cracking dan hancurnya matrix dalam tegangan [4]. Propertis material komposit yang digunakan dalam simulasi ini serupa dengan material yang digunakan oleh Zhang (2018) [6] dan mechanical properties dapat dilihat pada Tabel 3 .

Tabel 3. Material Properties Komposit Serat Karbon T300/Epoxy

\begin{tabular}{lc}
\hline \multicolumn{1}{c}{ Propertis } & Nilai \\
\hline $\begin{array}{l}\text { Poisson Ratio } \\
\text { Longitudinal Tensile } \\
\text { Strength }(\mathrm{MPa})\end{array}$ & 0.3 \\
$\begin{array}{l}\text { Longitudinal Compresse } \\
\text { Strength }(\mathrm{MPa})\end{array}$ & 1860 \\
$\begin{array}{l}\text { Transversal Tensile } \\
\text { Strength }(\mathrm{MPa})\end{array}$ & 1470 \\
$\begin{array}{l}\text { Transversal Compresse } \\
\text { strength }(\mathrm{MPa})\end{array}$ & 76 \\
$\begin{array}{l}\text { Ultimate in plane Shear } \\
\text { Strength } \text { (MPa) }\end{array}$ & 250 \\
\hline Sumber: Zhang, 2018 & 70 \\
\end{tabular}

Rigid wall sebagai papan yang akan digunakan sebagai penguji tabrak, dibuat dalam bentuk persegi dengan panjang sisi 2 meter. Tebal dari rigid wall ini dapat diabaikan mengingat papan ini didefinisikan sebagai papan rigid yang tidak akan mengalami deformasi ketika ditabrak oleh frame sepeda. Papan ini didefinisikan sebagai papan rigid agar ketika proses tabrakan terjadi, energi kinetik dan momentum yang terdapat pada frame sepeda sepenuhnya terserap oleh frame sepeda. Kondisi computational domain dapat dilihat pada Gambar 2. Gambar 2a menunjukkan gambar frame dan juga papan yang belum dilakukan proses assembly dan Gambar 2b menunjukkan kondisi assembly ketika frame sepeda akan menumbuk papan.

Pada simulasi ini jarak frame sepeda dengan papan diatur dengan jarak yang sekecil mungkin, sehingga didapatkan proses simulasi yang memakan waktu lebih sedikit. Didalam simulasi tumbukan eksplisit dinamik ini, kecepatan dari frame yang digerakkan didefinisikan mempunyai kecepatan yang konstan sehingga dapat dikatakan tidak ada proses akselerasi dari benda diam menuju 
kecepatan tertentu. Sehingga seberapapun jarak antara frame dengan papa yang ditabrak, tidak akan mempengaruhi besarnya energi kinetic frame sepeda.

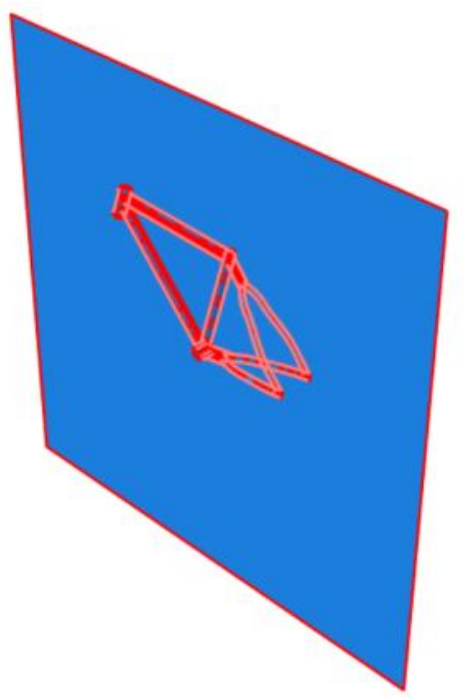

(a)

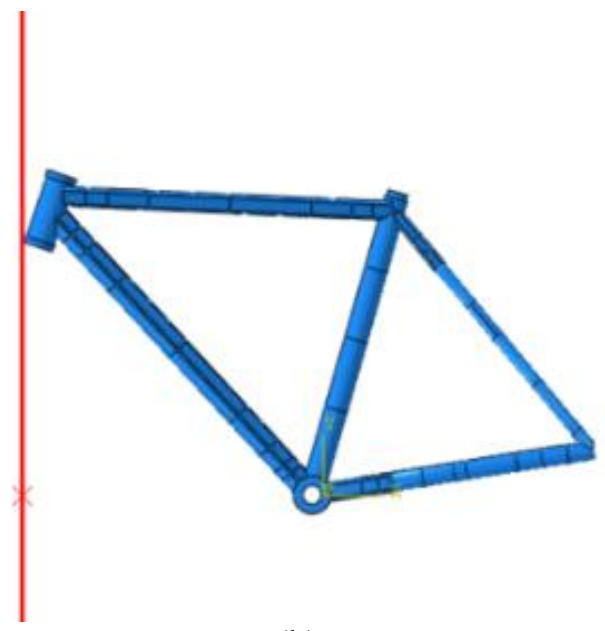

(b)

Gambar 2. Assembly frame Karbon dan Dinding

(a) Kondisi Awal saat Menggabungkan Sepeda dan Dinding (b) Kondisi Akhir Setelah Assembly

Di dalam proses simulasi eksplisit dinamik hal selanjutnya yang perlu dilakukan adalah mendefinisikan hubungan antara setiap part dan juga hubungan antara frame dengan plat yang akan ditabrak. Pada simulasi tabrakan ini hubungan antara frame sepeda dengan plat yang ditabrakan digunakan tipe kontak berupa explicit general contact dan kekasaran permukaan pada plat yang akan ditabrak digunakan koefisien gesek sebesar 0.4 . Plat yang akan ditabrak didefinisikan sebagai benda rigid yang tidak akan mengalami pergerakan, sedangkan frame sepeda sendiri di definisikan sebagai benda yang bergerak dengan kecepatan antara lain $5 \mathrm{~m} / \mathrm{s}, 10 \mathrm{~m} / \mathrm{s}$ dan $15 \mathrm{~m} / \mathrm{s}$.

\subsection{Grid Independency Test}

Untuk memastikan bahwa hasil simulasi tidak terpengaruh oleh kondisi mesh pada model maka sangat perlu dilakukan proses grid independency test. Proses ini dilakukan dengan melakukan mesh pada model dengan ukuran mesh yang berbeda. Pada proses grid independency test pada model ini dilakukan dalam empat ukuran elemen mesh yang berbeda. Jumlah nodes pada model akan menyesuaikan dengan ukuran elemen mesh. Semakin kecil ukuran mesh maka jumlah nodes pada satu model akan semakin banyak. Ukuran mesh pada grid independency test dalam penelitian ini akan dilihat pengaruhnya terhadap besarnya energi yang diserap oleh frame sepeda hasil dari grid independency test dapat dilihat pada Gambar 3 dibawah ini. Hasil dari grid independency test menunjukkan bahwa pada rentang ukuran mesh 5 $\mathrm{mm}$ - $12 \mathrm{~mm}$ tidak mempengaruhi hasil simulasi secara signifikan mengingat deviasi hasil simulasi yang dihasilkan $+/-0.6 \%$, sehingga pada penelitian ini dipilih ukuran mesh $10 \mathrm{~mm}$ untuk mengurangi beban komputasi yang terlalu berat apabila dilakukan dengan menggunakan ukuran mesh yang terlampau kecil.

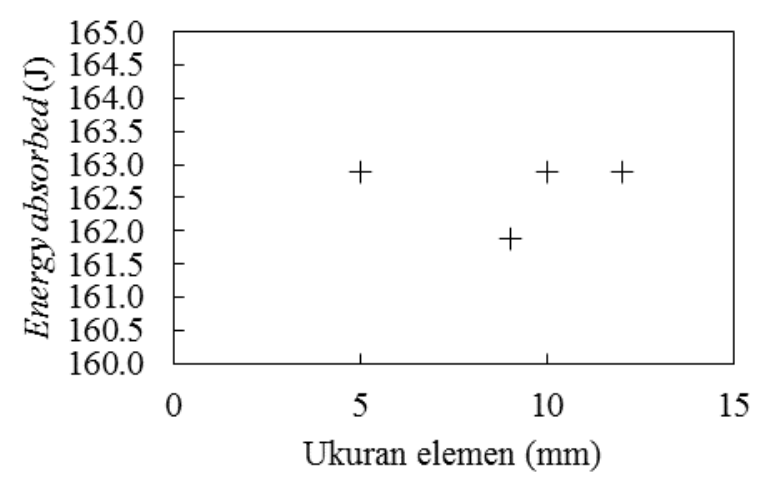

Gambar 3. Hasil Grid Independency Test 


\section{HASIL DAN PEMBAHASAN}

\subsection{Penyerapan Energi Kinetik pada Frame Sepeda}

Energi kinetik yang timbul akibat sepeda yang dipacu pada kecepatan tertentu akan diserap oleh frame sepeda ketika sepeda mengalami tabrakan. Apabila besarnya energi ini melebihi kemampuan frame untuk menyerap maka frame sepeda akan mengalami proses deformasi plastis dan pada tingkat selanjutnya akan terjadi kegagalan struktur pada frame.

Istilah crash impact dengan crush impact memiliki dua pemahaman yang berbeda. Crush impact merupakan proses penghancuran material dengan cara diletakkan di antara dua bidang yang bergerak dan sama sekali tidak terjadi proses bouncing. Apabila sebuah material dilakukan proses crush impact tentu besarnya energi yang dapat diserap pada sebuah material akan sangat besar mengingat crush impact dilakukan hingga material tersebut hancur. Sedangkan crash impact merupakan proses tabrakan yang melibatkan proses bouncing. Didalam paper ini, frame sepeda ditabrakkan pada dinding yang rigid dengan kecepatan tertentu sehingga frame sepeda akan mengalami kontak dengan dinding dalam waktu yang cukup singkat. Pada tabrakan yang terjadi dalam waktu yang cukup singkat ini, sebuah frame sepeda akan menerima dan meredam energi dari proses tabrakan. Apabila energi yang diterima terlalu besar maka akan terjadi proses deformasi hingga patah. Gambar 4 menunjukkan profil energi yang diserap oleh frame sepeda dengan ukuran standar apabila dilakukan simulasi tabrakan. Dari gambar tersebut terlihat bahwa semakin tinggi kecepatan maka besarnya energi yang akan diterima oleh frame sepeda akan semakin besar. Energi maksimum terdapat pada waktu 0.0003 detik frame akan memantul setalah waktu tersebut.

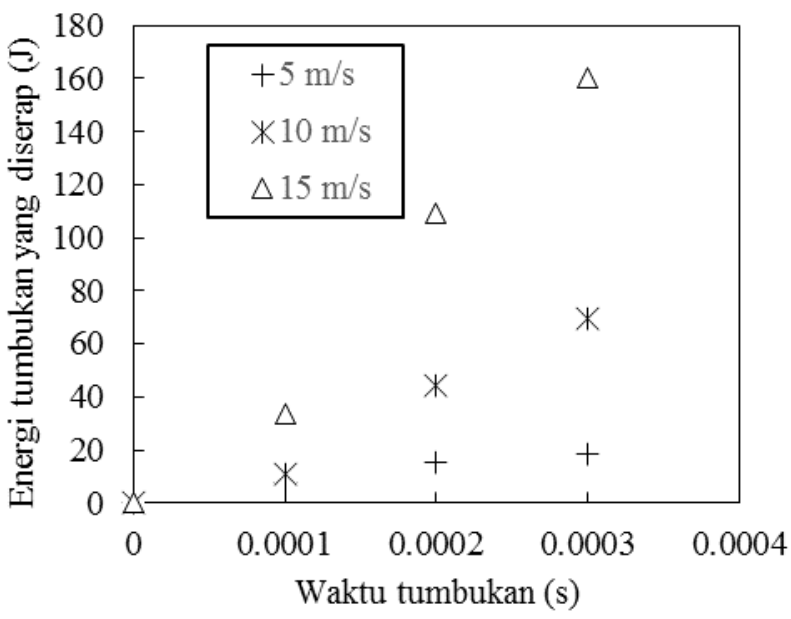

Gambar 4. Energi yang Diserap pada Frame Sepeda Original

\subsection{Energi yang diserap pada Frame Sepeda}

Gambar 5 dan Gambar 6 menunjukkan besarnya energi tumbukan yang dapat diserap oleh frame sepeda karbon pada beberapa kecepatan. Pada gambar tersebut besarnya energi yang diserap akan terus meningkat seiring dengan lamanya waktu kontak dari frame sepeda dengan permukaan padat. Waktu sentuh frame sepeda terhadap papan rigid tersebut merupakan lamanya waktu frame tersebut mengalami kontak dengan bidang yang ditabrak sebelum memantul.

Gambar 5 A-C merupakan profil energi ketika frame sepeda menumbuk permukaan dengan kecepatan 5-10 $\mathrm{m} / \mathrm{s}$ saat sepeda mengalami modifikasi pada bagian Head Tube Angle (H). Dari gambar tersebut terlihat bahwa modifikasi H6 memiliki tingkat penyerapan energi yang relatif lebih tinggi dibandingkan dengan modifikasi head tube yang lain. Hal ini disebabkan karena modifikasi head tube angle yang lebih besar dari desain awal dapat mempengaruhi distribusi gaya pada frame. Sedangkan pada Gambar 6 A-C menunjukkan pola penyerapan energi pada frame yang mengalami modifikasi pada bagian top tube angle. Serupa dengan hasil yang ditunjukkan pada Gambar 5 A-C, kode frame T6 mengalami penyerapan energi yang relatif lebih besar dibandingkan dengan kode frame yang lain. 
Namun pada kecepatan $15 \mathrm{~m} / \mathrm{s}$ modifikasi T6 memiliki kemampuan penyerapan energi yang relatif kecil.

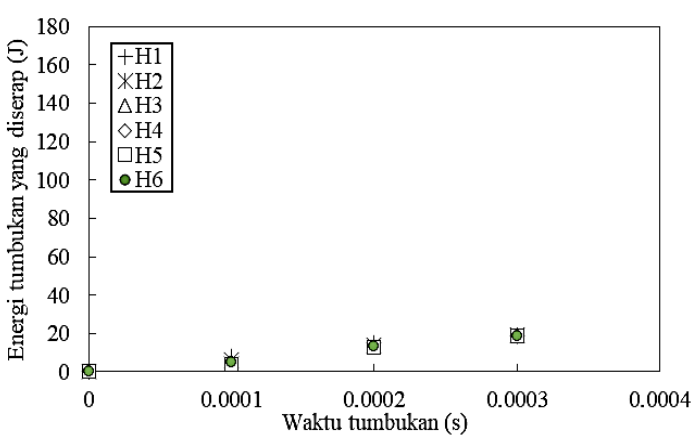

(a)

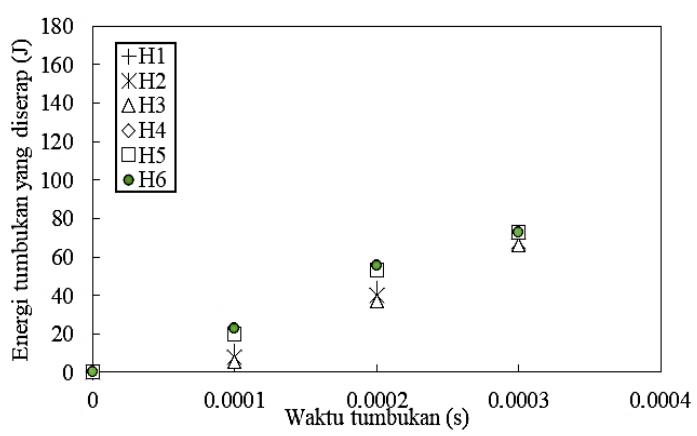

(b)

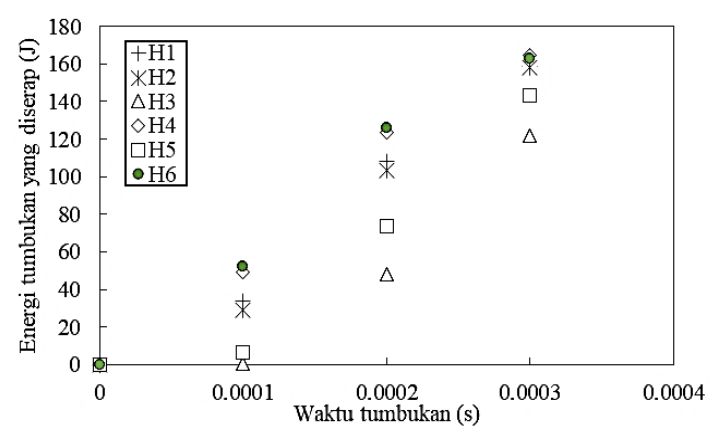

(c)

Gambar 5. Energi Tumbukan pada Frame yang telah Dimodifikasi (a) Modifikasi pada Head Tube Angle (Kecepatan Tabrakan $5 \mathrm{~m} / \mathrm{s}$ ), (b) Modifikasi pada Head Tube Angle (Kecepatan Tabrakan 10 m/s), (c) Modifikasi pada Head Tube Angle (Kecepatan Tabrakan 15 m/s),

Dari hasil nilai penyerapan energi yang terjadi pada frame sepeda tersebut maka perlu dilakukan inspeksi hasil elemen hingga khususnya nilai tegangan pada struktur rangka untuk mengetahui hubungan antara besarnya penyerapan energi pada frame sepeda saat terjadi crash impact terhadap besarnya tegangan kritis yang muncul pada beberapa titik kritis pada frame sepeda.

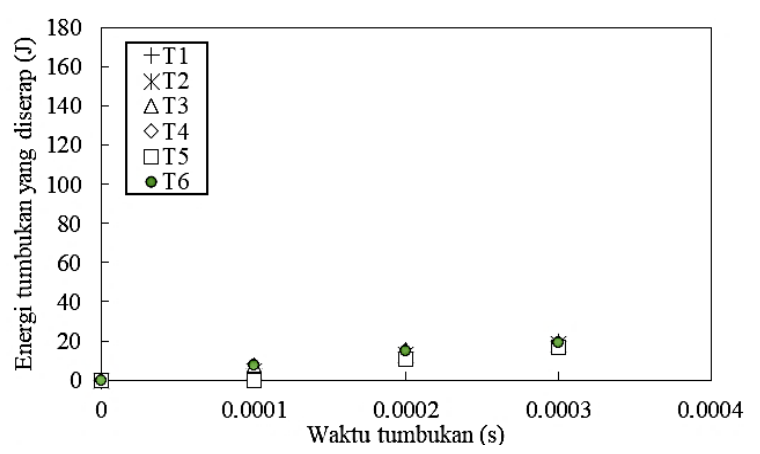

(a)

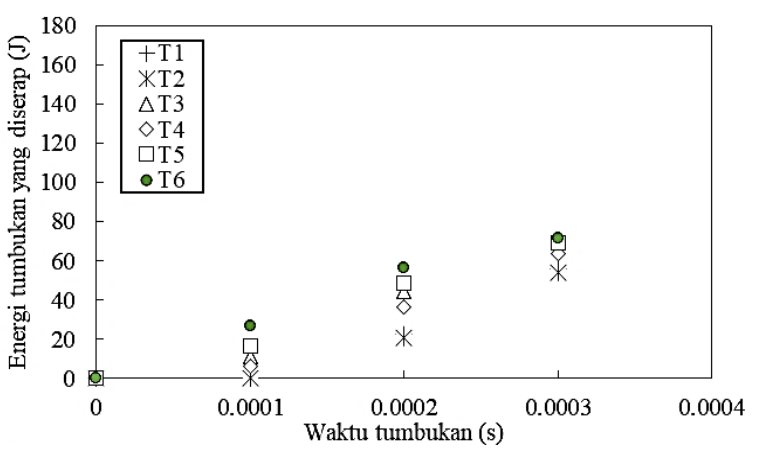

(b)

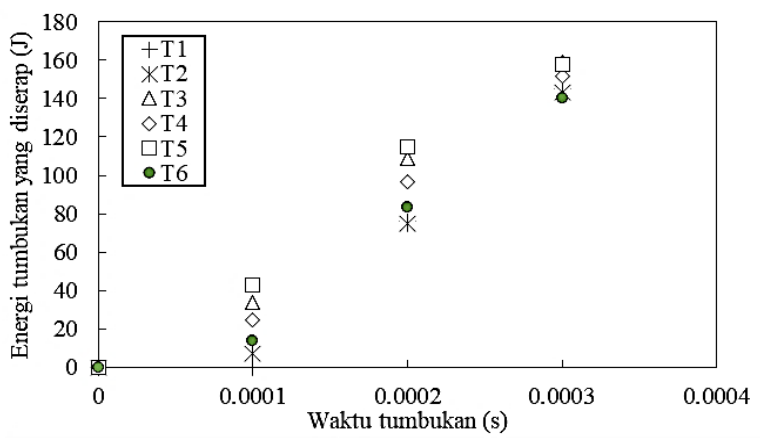

(c)

Gambar 6. Energi Tumbukan pada Frame yang Telah Dimodifikasi (a) Modifikasi pada Top Tube Angle (Kecepatan Tabrakan $5 \mathrm{~m} / \mathrm{s}$ ), (b) Modifikasi pada Top Tube Angle (Kecepatan Tabrakan 10 m/s), (c) Modifikasi pada Top Tube Angle (Kecepatan Tabrakan 15 m/s)

\subsection{Analisis tegangan kritis pada Frame Sepeda}

Untuk mengetahui pengaruh antara penyerapan energi pada frame sepeda terhadap besarnya 
tegangan kritis yang dialami pada frame sepeda maka analisis tegangan perlu dilakukan. Gambar 7 menunjukkan posisi - posisi kritis pada frame sepeda yang akan dipantau ketika perubahan geometri sepeda dilakukan.

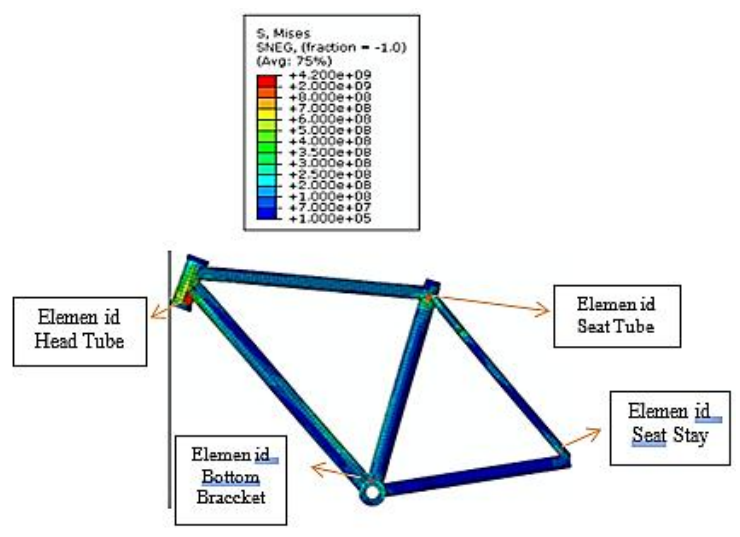

Gambar 7. Posisi Titik Kritis yang Ditinjau

Tabel 4. Tegangan Kritis pada Head Tube

\begin{tabular}{cccc}
\hline \multicolumn{2}{c}{ Kecepatan $5 \mathrm{~m} / \mathrm{s}$} & Kecepatan $10 \mathrm{~m} / \mathrm{s}$ & $\begin{array}{c}\text { Kecepatan 15 } \\
\mathrm{m} / \mathrm{s}\end{array}$ \\
\hline Kode & $\begin{array}{c}\text { Tengangan } \\
\text { Nama }\end{array}$ & Tengangan (MPa) & $\begin{array}{c}\text { Tengangan } \\
(\mathrm{MPa})\end{array}$ \\
\hline H1 & 399 & 809 & 1.210 \\
H2 & 343 & 730 & 1.060 \\
H3 & 356 & 696 & 1.050 \\
H4 & 352 & 708 & 1.090 \\
H5 & 355 & 699 & 1.050 \\
H6 & 344 & 685 & 1.030 \\
\hline Kecepatan 5 m/s & Kecepatan $10 \mathrm{~m} / \mathrm{s}$ & $\begin{array}{c}\text { Kecepatan } 15 \\
\text { m/s }\end{array}$ \\
\hline Kode & Tengangan & Tengangan & Tengangan \\
Nama & $($ MPa) & $($ MPa) & $($ MPa) \\
\hline T1 & 345 & 727 & 1.170 \\
T2 & 355 & 700 & 1.060 \\
T3 & 364 & 721 & 1.050 \\
T4 & 366 & 720 & 1.110 \\
T5 & 315 & 640 & 958 \\
T6 & 291 & 597 & 864 \\
\hline
\end{tabular}

Pada simulasi ini tegangan ijin (tegangan maksimum) yang menjadi acuan untuk mengetahui bahwa struktur telah mengalami kerusakan adalah tegangan maksimum pada komposit T300/Epoxy dengan besar tegangan maksimum sebesar 580 MPa [4]. Hasil simulasi nilai tegangan kritis pada bagian head tube telah ditunjukkan pada Tabel 4 .
Berdasarkan hasil tersebut dapat diketahui bahwa perubahan sudut pada HTA dan TTA tidak terlalu berpengaruh terhadap besarnya tegangan kritis pada bagian head tube. Hal ini terbukti bahwa perubahan tegangan kritis pada bagian critical point head tube tidak berubah secara signifikan. Meski demikian terlihat pada modifikasi kode T6 memiliki tegangan yang relatif lebih kecil dibandingkan dengan model desain yang lain ketika frame mengalami crash impact pada kecepatan $5 \mathrm{~m} / \mathrm{s}$.

Tabel 4 menunjukkan bahwa modifikasi T6 mengalami tegangan kritis terkecil diantara modifikasi yang lain pada kecepatan $5 \mathrm{~m} / \mathrm{s}$ dan 10m/s. Hal ini dapat disimpulkan bahwa penyerapan energi pada frame sepeda berbanding lurus dengan besarnya tegangan kritis pada frame sepeda. Hal ini disebabkan karena pada T6 tegangan dapat terbagi secara merata pada seluruh frame. Sedangkan pada kecepatan $15 \mathrm{~m} / \mathrm{s}$ nilai tegangan kritis pada T6 memang paling rendah, namun demikian terlihat bahwa nilai tersebut telah berada diatas tegangan ijin dari komposit serat karbon. Dengan melihat karakteristik dari komposit serat karbon T300/epoxy pada Gambar 8 dibawah ini. Dapat dipastikan apabila material telah melewati tegangan ijin (tegangan maksimal), dalam hal ini $580 \mathrm{MPa}$ untuk T300/Epoxy, maka material pada struktur tersebut telah mengalamai kerusakan. Sehingga dapat disimpulakan pada Tabel 4 tersebut, ketika frame sepeda mengalami crash impact dengan kecepatan $10 \mathrm{~m} / \mathrm{s}$ dan $15 \mathrm{~m} / \mathrm{s}$ maka bagian head tube telah mengalami kerusakan.

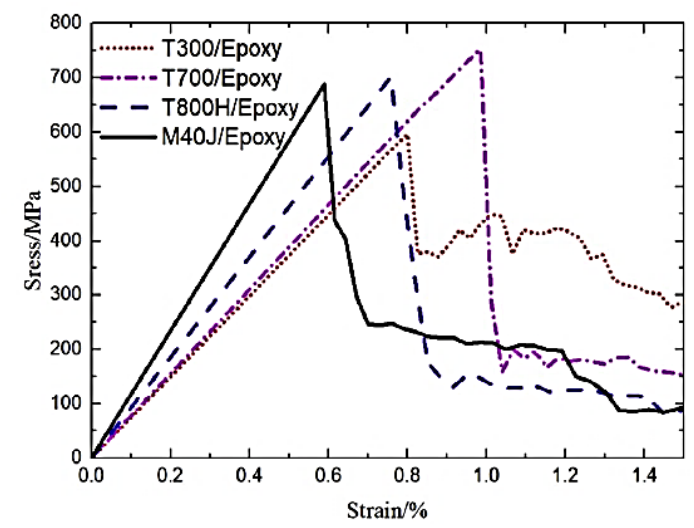

Gambar 8. Karakteristik Komposit Serat Karbon [4] 
Tabel 4 diatas juga telah menunjukkan bahwa perubahan TTA maupun HTA akan memperkecil tegangan pada struktur rangka sepeda, meskipun pada kecepatan 10 dan $15 \mathrm{~m} / \mathrm{s}$ bagian sambungan head tube akan mengalami kerusakan.

Selanjutnya untuk mengetahui pengaruh modifikasi HTA dan TTA pada bagian lain pada sepeda, pada data Tabel 5, dapat dilihat tegangan kritis pada bagian seat tube. Tegangan paling besar terjadi pada frame $\mathrm{H} 1$ yang menabrak pada kecepatan $5 \mathrm{~m} / \mathrm{s}, 10 \mathrm{~m} / \mathrm{s}$.

Tabel 5. Tegangan Kritis pada Seat Tube

\begin{tabular}{|c|c|c|c|}
\hline \multicolumn{2}{|c|}{ Kecepatan $5 \mathrm{~m} / \mathrm{s}$} & \multirow{2}{*}{$\begin{array}{l}\text { Kecepatan } 10 \mathrm{~m} / \mathrm{s} \\
\text { Tengangan }(\mathrm{MPa})\end{array}$} & \multirow{2}{*}{$\begin{array}{c}\begin{array}{c}\text { Kecepatan } 15 \\
\mathrm{~m} / \mathrm{s}\end{array} \\
\begin{array}{c}\text { Tengangan } \\
(\mathrm{MPa})\end{array}\end{array}$} \\
\hline $\begin{array}{l}\text { Kode } \\
\text { Nama }\end{array}$ & $\begin{array}{l}\text { Tengang } \\
\text { an (MPa) }\end{array}$ & & \\
\hline H1 & 268 & 585 & 849 \\
\hline $\mathrm{H} 2$ & 177 & 376 & 504 \\
\hline $\mathrm{H} 3$ & 202 & 431 & 661 \\
\hline $\mathrm{H} 4$ & 265 & 543 & 814 \\
\hline H5 & 227 & 458 & 705 \\
\hline H6 & 236 & 459 & 658 \\
\hline \multicolumn{2}{|c|}{ Kecepatan 5 m/s } & Kecepatan 10 m/s & $\begin{array}{c}\text { Kecepatan } 15 \\
\mathrm{~m} / \mathrm{s}\end{array}$ \\
\hline $\begin{array}{l}\text { Kode } \\
\text { Nama }\end{array}$ & $\begin{array}{c}\text { Tengang } \\
\text { an } \\
(\mathrm{MPa})\end{array}$ & $\begin{array}{c}\text { Tengangan } \\
(\mathrm{MPa})\end{array}$ & $\begin{array}{l}\text { Tengangan } \\
(\mathrm{MPa})\end{array}$ \\
\hline $\mathrm{T} 1$ & 212 & 449 & 651 \\
\hline $\mathrm{T} 2$ & 208 & 436 & 615 \\
\hline $\mathrm{T} 3$ & 216 & 404 & 616 \\
\hline $\mathrm{T} 4$ & 208 & 424 & 633 \\
\hline T5 & 206 & 422 & 634 \\
\hline T6 & 204 & 439 & 707 \\
\hline
\end{tabular}

Kemudian pada Tabel 6 juga ditunjukkan tegangan kritis pada bagian seat stay. Tiga bagian yaitu head tube, seat tube, dan seat stay, merupakan bagian paling kritis dimana bagian tersebut terdapat beberapa sambungan antara struktur sepeda, sehingga pada bagian ini pula yang akan mengalami kerusakan pertama saat sepeda mengalami benturan. Dari ketiga tabel diatas (Tabel 4, Tabel 5 dan Tabel 6) dapat disimpulkan bahwa H6 dan T6 cenderung memiliki ketahanan yang baik terhadap benturan. Hal ini dapat dilihat dari hasil simulasi elemen hingga, bahwa tegangan kritis pada Tabel 4 untuk
T6, meskipun pada tabrakan $10 \mathrm{~m} / \mathrm{s}$ dan $15 \mathrm{~m} / \mathrm{s}$ material telah mengalami kerusakan namun jika diasumsikan material tidak hancur maka tegangan kritis yang terjadi pada bagian head tube paling kecil ada T6. Namun pada bagian seat stay dan seat tube modifikasi ini sangat tidak menguntungkan mengingat struktur akan mengalami kerusakan ketika terjadi tabrakan pada $15 \mathrm{~m} / \mathrm{s}$ (pada seat stay) dan $10 \mathrm{~m} / \mathrm{s}$ (pada seat stay). Sehingga modifikasi yang disarankan adalah H6.

Tabel 6. Tegangan Kritis Seat Stay pada Frame Sepeda

\begin{tabular}{|c|c|c|c|}
\hline \multicolumn{2}{|c|}{ Kecepatan $5 \mathrm{~m} / \mathrm{s}$} & Kecepatan 10 & Kecepatan 15 \\
\hline $\begin{array}{l}\text { Kode } \\
\text { Nama }\end{array}$ & $\begin{array}{c}\text { Tengangan } \\
\text { (MPa) }\end{array}$ & $\begin{array}{c}\text { Tengangan } \\
\text { (MPa) }\end{array}$ & $\begin{array}{l}\text { Tengangan } \\
\text { (MPa) }\end{array}$ \\
\hline H1 & 360 & 550 & 685 \\
\hline $\mathrm{H} 2$ & 236 & 582 & 895 \\
\hline H3 & 243 & 460 & 743 \\
\hline $\mathrm{H} 4$ & 332 & 709 & 1.070 \\
\hline H5 & 236 & 504 & 804 \\
\hline H6 & 291 & 463 & 693 \\
\hline \multicolumn{2}{|c|}{ Kecepatan $5 \mathrm{~m} / \mathrm{s}$} & $\begin{array}{c}\text { Kecepatan } 10 \\
\mathrm{~m} / \mathrm{s}\end{array}$ & $\begin{array}{c}\text { Kecepatan } 15 \\
\mathrm{~m} / \mathrm{s}\end{array}$ \\
\hline $\begin{array}{l}\text { Kode } \\
\text { Nama }\end{array}$ & $\begin{array}{c}\text { Tengangan } \\
(\mathrm{MPa})\end{array}$ & $\begin{array}{c}\text { Tengangan } \\
\text { (MPa) }\end{array}$ & $\begin{array}{l}\text { Tengangan } \\
\text { (MPa) }\end{array}$ \\
\hline $\mathrm{T} 1$ & 285 & 544 & 833 \\
\hline $\mathrm{T} 2$ & 249 & 455 & 759 \\
\hline $\mathrm{T} 3$ & 227 & 482 & 771 \\
\hline $\mathrm{T} 4$ & 323 & 595 & 880 \\
\hline T5 & 328 & 604 & 893 \\
\hline T6 & 331 & 629 & 913 \\
\hline
\end{tabular}

Hasil analisa tegangan kritis pada simulasi tabrakan ini, H6 cenderung memberikan hasil yang cukup stabil dalam hal keamanan. Hal ini dapat dilihat dari tegangan kritis pada head tube yang relatif kecil pada kecepatan tumbukan $10 \mathrm{~m} / \mathrm{s}$, kemudian pada bagian seat tube juga cenderung kecil dan pada bagian seat stay teganan kritis yang dihasilkan tergolong kecil. H2 juga memiliki peluang menjadi rekomendasi mengingat pada kecepatan tabrakan $15 \mathrm{~m} / \mathrm{s}$ bagian seat tube tegangan kritis tidak melampaui tegangan maksimal, namun demikian nilai tegangan pada titik lain terlihat relatif tidak stabil dibandingkan 
dengan frame H6. Apabila hal ini dikaitkan dengan hasil analisa penyerapan energi pada Gambar 5, hal ini dapat disimpulkan bahwa besarnya energi yang dapat diserap oleh frame sepeda sangat mempengaruhi ketangguhan frame sepeda itu sendiri. Dari hasil penelitian ini diketahui bahwa semakin besar tingkat penyerapan energi pada frame sepeda menunjukkan tingkat ketahanan frame sepeda terhadap crash impact juga meningkat.

\subsection{Deformasi dan Defleksi pada Frame Sepeda}

Setelah melihat hubungan antara tingkat penyerapan energi beserta tegangan kritis pada frame sepeda, dapat dinyatakan bahwa frame $\mathrm{H} 6$ memiliki tingkat stabilitas keamanan yang baik. oleh karenan itu perlu dilakukan analisa selanjutnya yaitu analisis deformasi dan defleksi pada frame speda ini. Pemilihan node untuk dipantau pada simulasi ini didasarkan pada hasil simulasi frame sepeda tanpa modifikasi. Pada warna kontur yang berwarna merah (Gambar 9) menunjukkan tingkat defleksi yang cukup tinggi.

Besarnya defleksi yang terjadi pada bagian head tube dapat dilihat pada Tabel 7. Berdasarkan analisa elemen hingga dan penyerapan energi, frame dengan kode H6 merupakan frame yang cukup unggul dibanding frame yang lain. Dengan melihat besarnya defleksi yang terjadi pada kecepatan $5 \mathrm{~m} / \mathrm{s}$ pada Tabel 7 terlihat bahwa masing masing frame memiliki rata - rata defleksi sebesar $0,7 \mathrm{~mm}$ sehingga bisa dikatakan perubahan sudut HTA maupun TTA ini tidak terlalu mempengaruhi besarnya defleksi pada bagian head tube.

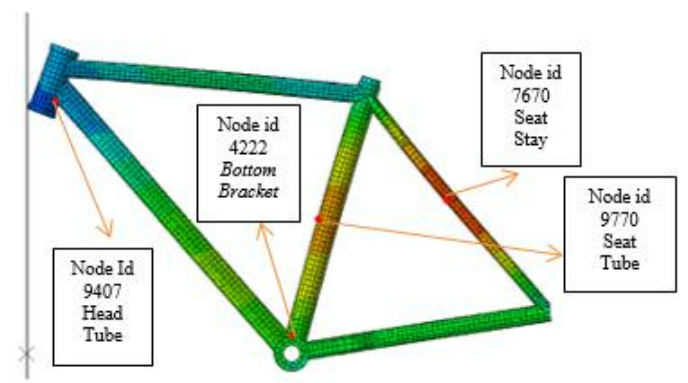

Gambar 9. Contoh Sampel Empat Parameter dalam Menganalisis Deformasi pada Sudut HTA
Tabel 7. Deformasi pada Head Tube pada Frame Sepeda

\begin{tabular}{|c|c|c|c|}
\hline \multicolumn{2}{|c|}{ Kecepatan 5 m/s } & Kecepatan 10 & Kecepatan 15 \\
\hline $\begin{array}{l}\text { Kode } \\
\text { Nama }\end{array}$ & $\begin{array}{l}\text { Defleksi } \\
(\mathrm{mm})\end{array}$ & Defleksi (mm) & Defleksi (mm) \\
\hline H1 & 0.72 & 1.05 & 1.4 \\
\hline $\mathrm{H} 2$ & 0.721 & 1.041 & 1.381 \\
\hline $\mathrm{H} 3$ & 0.746 & 1.076 & 1.376 \\
\hline $\mathrm{H} 4$ & 0.741 & 1.081 & 1.421 \\
\hline H5 & 0.757 & 1.087 & 1.447 \\
\hline H6 & 0.711 & 1.051 & 1.401 \\
\hline \multicolumn{2}{|c|}{ Kecepatan 5 m/s } & $\begin{array}{c}\text { Kecepatan } 10 \\
\mathrm{~m} / \mathrm{s}\end{array}$ & $\begin{array}{c}\text { Kecepatan } 15 \\
\mathrm{~m} / \mathrm{s}\end{array}$ \\
\hline $\begin{array}{l}\text { Kode } \\
\text { Nama }\end{array}$ & $\begin{array}{l}\text { Defleksi } \\
(\mathrm{mm})\end{array}$ & Defleksi (mm) & Defleksi (mm) \\
\hline $\mathrm{T} 1$ & 0.788 & 1.128 & 1.498 \\
\hline $\mathrm{T} 2$ & 0.736 & 1.066 & 1.416 \\
\hline $\mathrm{T} 3$ & 0.738 & 1.076 & 1.416 \\
\hline $\mathrm{T} 4$ & 0.716 & 1.046 & 1.386 \\
\hline $\mathrm{T} 5$ & 0.72 & 1.05 & 1.38 \\
\hline T6 & 0.71 & 1.03 & 1.34 \\
\hline
\end{tabular}

Tabel 8. Deformasi pada Seat Tube pada Frame Sepeda

\begin{tabular}{|c|c|c|c|}
\hline \multicolumn{2}{|c|}{ Kecepatan 5 m/s } & $\begin{array}{c}\text { Kecepatan } 10 \\
\mathrm{~m} / \mathrm{s}\end{array}$ & $\begin{array}{c}\text { Kecepatan } 15 \\
\text { m/s }\end{array}$ \\
\hline $\begin{array}{l}\text { Kode } \\
\text { Nama }\end{array}$ & $\begin{array}{l}\text { Defleksi } \\
(\mathrm{mm})\end{array}$ & Defleksi (mm) & Defleksi (mm) \\
\hline $\mathrm{H} 1$ & 2.13 & 3.77 & 5.44 \\
\hline $\mathrm{H} 2$ & 2.121 & 3.721 & 5.421 \\
\hline $\mathrm{H} 3$ & 2.026 & 3.746 & 5.416 \\
\hline $\mathrm{H} 4$ & 2.121 & 3.531 & 5.461 \\
\hline H5 & 2.027 & 3.767 & 5.447 \\
\hline H6 & 2.101 & 3.761 & 5.421 \\
\hline \multicolumn{2}{|c|}{ Kecepatan 5 m/s } & $\begin{array}{c}\text { Kecepatan } 10 \\
\mathrm{~m} / \mathrm{s}\end{array}$ & $\begin{array}{c}\text { Kecepatan } 15 \\
\mathrm{~m} / \mathrm{s}\end{array}$ \\
\hline $\begin{array}{l}\text { Kode } \\
\text { Nama }\end{array}$ & $\begin{array}{l}\text { Defleksi } \\
(\mathrm{mm})\end{array}$ & Defleksi (mm) & Defleksi (mm) \\
\hline $\mathrm{T} 1$ & 2.158 & 3.828 & 5.468 \\
\hline $\mathrm{T} 2$ & 2.096 & 3.496 & 5.406 \\
\hline $\mathrm{T} 3$ & 2.096 & 3.746 & 5.436 \\
\hline $\mathrm{T} 4$ & 2.106 & 3.836 & 5.456 \\
\hline $\mathrm{T} 5$ & 2.11 & 3.81 & 5.49 \\
\hline T6 & 2.17 & 3.81 & 5.49 \\
\hline
\end{tabular}


Selanjutnya untuk memastikan bahwa perubahan HTA dan TTA ini tidak berpengaruh pada besarnya defleksi pada rangka sepeda, pengecekan tingkat defleksi dilanjutkan pada bagian seat tube dan seat stay. Tabel 8 menunjukkan besarnya defleksi yang terjadi pada bagian seat tube. Pada Tabel 8 tersebut deformasi terkecil terjadi pada frame $\mathrm{H6}$ pada kecepatan tabrakan $15 \mathrm{~m} / \mathrm{s}$. Namun demikian, pada Tabel 8 tersebut dapat dipastikan bahwa efek perubahan HTA dan TTA tidak berpengaruh secara signifikan terhadap besarnya defleksi yang terjadi pada struktur, hal ini ditunjukkan dengan nilai rata - rata masing masing defleksi tidak jauh berbeda.

Tabel 9. Deformasi pada Seat Stay pada Frame Sepeda

\begin{tabular}{|c|c|c|c|}
\hline \multicolumn{2}{|c|}{ Kecepatan 5 m/s } & \multirow{2}{*}{$\begin{array}{c}\begin{array}{c}\text { Kecepatan } 10 \\
\mathrm{~m} / \mathrm{s}\end{array} \\
\text { Defleksi (mm) }\end{array}$} & \multirow{2}{*}{$\begin{array}{c}\begin{array}{c}\text { Kecepatan } 15 \\
\mathrm{~m} / \mathrm{s}\end{array} \\
\text { Defleksi (mm) }\end{array}$} \\
\hline $\begin{array}{l}\text { Kode } \\
\text { Nama }\end{array}$ & $\begin{array}{l}\text { Defleksi } \\
(\mathrm{mm})\end{array}$ & & \\
\hline $\mathrm{H} 1$ & 2.47 & 4.83 & 7.1 \\
\hline $\mathrm{H} 2$ & 2.521 & 4.781 & 7.021 \\
\hline $\mathrm{H} 3$ & 2.356 & 4.566 & 6.656 \\
\hline $\mathrm{H} 4$ & 2.561 & 4.731 & 6.961 \\
\hline H5 & 2.487 & 4.627 & 6.887 \\
\hline H6 & 2.531 & 4.641 & 6.821 \\
\hline \multicolumn{2}{|c|}{ Kecepatan $5 \mathrm{~m} / \mathrm{s}$} & $\begin{array}{c}\text { Kecepatan } 10 \\
\mathrm{~m} / \mathrm{s}\end{array}$ & $\begin{array}{l}\text { Kecepatan } 15 \\
\mathrm{~m} / \mathrm{s}\end{array}$ \\
\hline $\begin{array}{l}\text { Kode } \\
\text { Nama }\end{array}$ & $\begin{array}{l}\text { Defleksi } \\
(\mathrm{mm})\end{array}$ & Defleksi (mm) & Defleksi (mm) \\
\hline $\mathrm{T} 1$ & 2.408 & 4.498 & 6.808 \\
\hline $\mathrm{T} 2$ & 2.446 & 4.556 & 6.866 \\
\hline $\mathrm{T} 3$ & 2.456 & 4.716 & 6.976 \\
\hline $\mathrm{T} 4$ & 2.596 & 4.856 & 7.196 \\
\hline T5 & 2.66 & 4.91 & 7.24 \\
\hline T6 & 2.58 & 4.79 & 7.26 \\
\hline
\end{tabular}

Selanjutnya, untuk memastikan bahwa perubahan HTA dan TTA ini tidak berpengaruh secara signifikan terhadap besarnya defleksi pada keseluruhan rangka sepeda maka perlu dilakukan pengecekan pada bagian seat stay (Tabel 9). Dari hasil tersebut terlihat bahwa perubahan HTA dan TTA memang tidak secara signifikan mempengaruhi besarnya defleksi pada masing masing bagian baik seat tube, head tube dan seat stay.

\section{KESIMPULAN DAN SARAN}

Setelah melakukan evaluasi frame sepeda balap dengan uji tabrakan menggunakan metode eksplisit dinamik, maka dari hasil uji tersebut dapat disimpulkan bahwa:

1. Besarnya energi yang dapat diserap oleh frame sepeda sangat mempengaruhi ketangguhan frame sepeda. Semakin besar tingkat penyerapan energi pada frame sepeda menunjukkan tingkat ketahanan frame sepeda terhadap crash impact juga semakin baik. Tingkat penyerapan energi semakin meningkat seiring dengan meningkatnya HTA.

2. Meskipun perubahan HTA dan TTA ini berpengaruh signifikan terhadap besarnya energi yang diserap frame ketika terhadi tabrakan dan berpengaruh pula pada tegangan maksimum pada beberapa titik kritis pada sepeda namun modifikasi ini tidak secara signifikan mempengaruhi besarnya defleksi pada masing masing bagian baik seat tube, head tube dan seat stay.

\section{DAFTAR PUSTAKA}

[1] Yehia. A., Abdel-nasser, "Frontal Crash Simulation of Vehicles Against Lighting Columns using FEM," Alexandria Engineering Journal, vol. 52, no 3, pp. 295-299, 2013, https://doi.org/10.1016/j.aej.2013.01.005.

[2] Junaidi, Taufik, "Proses Manufaktur Sepeda Balap dari Bahan Serat Karbon dengan Metode Wraped on Foam," Yogyakarta, Indonesia: Universitas Gadjah Mada, 2016

[3] Lin, C. C., Huang, S. J., Liu, C. C. , "Structural Analysis and Optimization of Bicycle Frame Designs," Advances in Mechanical Engineering,vol 9, no 12, pp. 1-10, 2017, https://doi.org/10.1177/1687814017739513

[4] Duarte A.P.C., A. Diaz Saez, N. Silvestre, "Comparative Study Between XFEM and Hashin Damage Criterion Applied to Failure of Composites," Elsevier:Thin-Walled Structures, no 115, pp.277-288, 2017, http://dx.doi.org/10.1016/j.tws.2017.02.020 
[5] P.J. Benjamin Hasseldine, Chao Gao, Yaning Li, "Prediction of The Anisotropic Damage Evolution of Dry Common Millet (Panicum Miliaceum) Seed Under Quasi-Static Blunt Indentation," Elsevier:Engineering Fracture Mechanics, no 214, pp.112-122, 2019, https://doi.org/10.1016/j.engfracmech.2019.03. $\underline{042}$
[6] Zhang, M., "Compressive Strength Determined for Ultrahigh Modulus Fiber Reinforced Composites by [ 90 / 0 ] ns Laminates," Elsevier: Composite Structures, no 191, pp. 24-35, 2018, https://doi.org/10.1016/j. compstruct. 2018.02.033 